特集記事ワークショップ報告

\title{
次世代シーケンサー時代の遺伝子発見法
}

土井一行 1)・那須田周平 2)・芦苅基行 3)

1) 名古屋大学大学院生命農学研究科附属フィールド科学教育研究センター東郷フィールド, 愛知県愛知郡東郷町, $\overline{7} 470-0151$

2) 京都大学大学院農学研究科, 京都市, 干 606-8502

3) 名古屋大学生物機能開発利用研究センター, 愛知県名古屋市, $\bar{T} 464-8601$

\section{How to discover new genes in NGS era}

Kazuyuki Doi ${ }^{1)}$, Shuhei Nasuda ${ }^{2)}$ and Motoyuki Ashikari ${ }^{3)}$

1) Togo Field, Graduate School of Bioagricultural Sciences, Nagoya University, Togo, Aichi 470-0151

2) Graduate School of Agriculture, Kyoto University, Kyoto 606-8502

3) Bioscience and Biotechnology Center, Nagoya University, Nagoya, Aichi 464-8601

\section{キーワード}

次世代シーケンサー (NGS), 遺伝統計学, フェノタイピング

\section{ワークショップのねらい}

次世代シーケンサー（NGS）の高度な能力に対応する 遺伝学・育種学はどのように発展するのか, 多くの研究 者が疑問を抱いているものの，明確な方向性は未だ示さ れていない. NGS データを活用した統計解析の枠組みは ぞのように発展しらるのか? 遺伝子を発見して活用する ためにはどのような研究材料が必要なのか? 育種に NGS をどのように活用できるのか? NGS に対応する大規模集 団の形質評価はどのよらに行らのか? など, 多くの人が もつ疑問に対し, 先進的な取り組及を行っている研究者 に話題をご提供いただき，議論を深めることを目的とした。

\section{演題 1 育種における遺伝統計学}

\section{田宮 元（東北大・東北メディカル・メガバンク機構）}

植物育種分野で，NGS により得られたゲノム情報を用 いて，重要な農業形質を支配する遺伝子の同定が試みら れている。もっとも普及した手法は，ゲノムワイドな SNP (一塩基多型)を用いたゲノムワイドアソシエーショ ン研究（GWAS）である。このSNP による GWAS は， ヒ トゲノム分野で開発された手法であり，七トと違い農作 物では, 前提となる重要な仮定のいくつかが破綻してい る。たと光ば，ヒトの GWAS の場合には，血縁によるゲ ノム共有が形質の類似性を支えるら゙ノム共有と交絡する こと（血縁交絡）を防ぐために，原則として 3 親等以内

2016 年 3 月 3 日受領

Correspondence: kdoi@agr.nagoya-u.ac.jp
の血縁者を排除する，あるいは集団分化による対立遺伝 子頻度分布差の交絡（集団階層化問題）を防ぐために, 同一地域集団（たとえば同一民族集団）からのサンプリ ングに限定する等の配慮がなされる (Price et al. 2010).

ところが，日本水稲の場合には，きつい近交によって 作出された品種が主であり，他方で，インディカ品種な ども利用される。このような集団の場合で，SNPによる GWAS を行うと, 血縁交絡や集団階層化のために検定統 計量がインフレーションを引き起こし，高い偽陽性率の ために，責任遺伝子の同定を困難にしてしまらだろう． 昨今, このような問題を解決するために, 混合線形モデ ルなども導入されているが，上記のような構造が変量効 果として扱えるのかぞらか不明である上，しばしば，同 じゲノム情報から，固定効果を同時に推定して利用する ケースが見受けられ，不適切な過剩調整を引き起こして いる。 さらには，GWAS に扔いて高度の多重検定を補正 する目的で導入されるゲノムワイド有意水準は単純にヒ トゲノムからの援用であり，統計的に意味を成していない．

以上の困難は, NGS データの利用に执いても変わりは なく, むしろ問題は深刻化すると予想される。昨今, 特 定の形質について，ゲノム情報で説明される遺伝率と古 典的な遺伝率との差（失われた遺伝率）が，ヒトだけで なく，動物・植物を含む育種対象となる生物に幅広く見 られることが分かってきているが，上記のよらな問題を 軽減・解決し, 柔軟な責任遺伝子の同定を行わない限り, 農作物では失われた遺伝率の問題に取り組むことさえ困 難になるだろう。

講演では，以上の問題を概観した上で，日本水稲での 全交配系図を利用して系図的血縁行列 (Speed and Balding 
2015）を構成し，集団構造の問題に取り組んだ結果を発 表した。他方で，このよらな交配系図情報をネットワー クグラフ理論（Barabasi and Albert 1999）に基づいて分析 することで, 日本水稲の交配育種の重要な問題点を定量 的に浮かび上がらせることに成功した.

\section{演題 2 コムギ倍数性シリーズ（AA, AABB, AABBDD） のコアコレクションの作成と利用 \\ 那須田周平 (京大院・農学)}

イネ科コムギ属に属するパンコムギ（Triticum aestivum) は世界三大穀類（イネ，コムギ，トウモロコ シ）の中で唯一ゲノム配列の解読が終わっていない植物 であった。 これは，パンコムギが 6 倍体であり，かつ， 構成する 2 倍体サブゲノムが巨大で反復配列に富んでい ることに起因する。ゲノム中に 3 重複する配列が存在す ることが, NGS を用いたショットガンシーケンスを阻ん できた。国際コムギゲノム配列解読コンソーシアムは, この障碍をコムギ遺伝学の伝統的手法である異数体系統 を用いることで回避した。すなおち，コムギの各染色体 を染色体腕ごとにフローソーティングで選り分けて, NGS でショットガンシーケンスしアセンブルした（IWGSC 2014).この研究によりパンコムギゲノムの概要配列（推 定されるコムギゲノムの約 $61 \%$ のカバー率）が利用可能 になり，約 10 万の遺伝子予測配列（gene models）のそれ ぞれについて，コムギの 21 本の染色体の特定の 1 本に存 在するかを推定できるよらになった。 6 倍体ゲノム中の 同祖遺伝子配列を区別する配列多型をウエットの実験を せずともデータベースから検索できるよらになったこと は，パンコムギに拈けるマーカ一開発，ひいては分子育 種を推進する研究基盤をコムギ研究コミュニティーが手 にしたことを意味する。

文部科学省ナショナルバイオリソースプロジェクト （NBRP）は，ライフサイエンス研究の基礎・基盤となる バイオリソース（生物遺伝資源）の収集・保存・提供を 行らことと, ゲノム情報等の解析などにより時代の要請 に応えたバイオリソースの整備を行らことを目的として いる。 コムギは平成 14 年から開始した NBRP 第一期か ら採択され，約 12,000の種子系統を保存している.コム ギリソースは，約 1,000 の実験系統（異数体や細胞質置 換系統などのパンコムギ標準品種 Chinese Spring を基軸 とした遺伝学実験系統群）と約 11,000 の野生種・在来系 統に大別され，コムギ属とそれに近縁な Aegilops 属のす ベての種を保存している．NBRP・コムギの野生種・在 来系統の大きな特徴は, コレクションの大部分が自生地 (在来系統に拈いては栽培地) に拈いて収集され，詳細な 採集地点の記録が残され，分布域をほぼカバーしている ことである。野生種や在来系統は，栽培品種よりも大き な遺伝的多様性を有するため, パンコムギの重要な育種 素材として認識されてきたが，コムギのゲノム配列情報 を活用できるようになり，育種への利用可能性がさらに
高まった。

我々は，NBRP・コムギの保存する 6 倍性（ゲノム構 成：AABBDD)，4 倍性（AABB），2 倍性（AA）のコム ギの遺伝的多様性を代表するコアコレクションの作成を 進めている. コアコレクション作成のスキームは, 全サ ンプルについて少数マーカーのジェノタイピングによる 遺伝的多様性の検出（6 倍性コムギについては，分類群 と地理的分布を多様性の指標の代替とした), 集団構造解 析と系統解析によるコアコレクション系統の選抜, コア コレクション系統のゲノムワイドマーカーによる高密度 ジェノタイピング，そして表現型調査である。6倍性コ ムギ約 6,500 系統を代表する 190 系統，4 倍性コムギ約 2,200 系統を代表する 190 系統，2 倍性コムギ約 600 系統 を代表する 160 系統を選抜し, 重点的にジェノタイピン グを進め, それぞれの倍数性レベルにおいてマーカーと 表現型の相関を解析できる研究基盤を構築することがで きた，実際に，コムギの穀粒に蓄積するカドミウム濃度 について相関解析を行らと，6 倍性コムギのコアコレク ションで有意な Marker-Trait Association（MAS）が検出 された第 3 , 第 5 , 第 7 同祖群染色体のらち第 5 染色体は 4 倍性コムギでも有意な MAS を示した. 現在, 国内のコ ムギ研究者らの協力を得て，コアコレクションを用いて 表現型調査を進めている．6倍性コムギと 4 倍性コムギ のコアコレクション系統はそれぞれ 2 系統の標準品種 $(6$ 倍性コムギは Chinese Spring と農林 61 号，4 倍性コムギ は Langdon と Kronos）と交配し，大部分について $F_{2}$ 集 団を作成してある。アソシエーション解析によって表現 型と相関のあるゲノム領域の存在が示唆されれば, 特定 交配組み合わせに基づくQTL 解析を直ちに行らことが可 能である。

\section{演題 3 イネ大規模突然変異集団と交配集団を用いた遺 伝子領域同定 \\ 寺内良平・阿部 陽・高木宏樹・神崎洋之・夏目 俊・八重 樫弘樹・宇津志博恵・植村亜衣子・神崎英子・タミルム ルネー（(公財）岩手生物工学研究センター）}

岩手県出資の基礎研究機関である (公財) 岩手生物工 学研究センターは, 岩手県農業研究センターと共同で, 岩手県の農林水産物の改良に取り組んでいる。発表者ら の研究グループでは, 水稲のゲノム育種を目的として, 次世代シーケンサーを活用したイネの有用遺伝子および QTL 同定を進めている. 講演では, 発表者らが作出育成 した水稲遺伝資源および全ゲノムシーケンスを利用した 有用遺伝子同定技術について概略を紹介した.

\section{1.「ひとめぼれ」EMS 突然変異系統}

発表者らは, 過去約 10 年にわたり, 東北地方の主力水 稲品種「ひとめぼれ」を材料として, EMS (ethyl methane sulfonate）処理により突然変異を誘導した系統群作出を 実施してきた（Rakshit et al. 2010）。現在までに計 12,000 
系統の変異系統を作出し, 系統維持している. 既に 50 個 体以上の突然变異系統の全ゲノムシーケンスを実施し, 「ひとめぼれ」親系統のゲノム配列と比較したところ，各 系統が平均 1,500 箇所の SNP を有することが明らかに なった，これら突然変異系統群は，さまざまな形質を示 し, 育種上重要な遺伝子の対立遺伝子を探索する上で, 有用性の高い遺伝資源であると考兄られる。

\section{2.「ひとめぼれ」大規模交配集団}

水稲の多様な品種が保有する自然变異を活用する目的 で,「ひとめぼれ」と世界の水稻の遺伝的多様性を代表す る約 20 の品種を交配し，1 種子更新法により $\mathrm{F}_{6}-\mathrm{F}_{9}$ 世代 を進めた組換兄近交系 (Recombinant Inbred Lines: RILs), 計 3,200 系統を育成して維持している。 これらの系統は, ほぼ純系であり，系統ごとに多数の個体を用いた形質調 查が可能であるため, 量的形質の遺伝解析に最適である. また，これら系統群を活用して，後述する QTL-seq 法の 適用，打よび Nested Association Mapping (NAM) 解析 (Yu et al. 2008)，エピスタシス解析などを進めている.

\section{3. 次世代シーケンサーによる全ゲノム解析技術, MutMap} 法および QTL-seq 法

上記突然变異系統群から有用性の高い形質を示寸系統 が得られた場合，その突然変異形質の原因遺伝子を同定 することが課題となる. MutMap 法 (Abe et al. 2012) は, 全ゲノムシーケンスにより突然変異原因遺伝子を同定す る技術である，注目する突然変異体を親系統（「ひとめぼ れ」）飞交配し， $F_{2}$ 世代で形質の分離を観察し，突然変 異形質を示す $\mathrm{F}_{2}$ 個体約 20 個体の DNA を等量プールし, 全ゲノムシーケンスに供する。特定の SNP 箇所倿対応す る全ショートリード中, 変異型ショートリードの割合を SNP-index と定義し，SNP-index が 100\%を示すゲノム領 域を同定することにより原因遺伝子を見つける技術であ る. また, 系統間交配後代の $F_{2}$ や RIL の子孫に执いて形 質が分離する場合, 形質値が両極端を示すような 2 種類 の個体群に注目し，2 種類の個体群のプール DNA を全ゲ ノムシーケンスに供し，その間で異なる SNP-indexを示 すゲノム領域を同定することにより，形質を支配する QTL を同定する技術が QTL-seq 法 (Takagi et al. 2013) で ある。これらの技術は，1ないし2 個のプールDNAを全 ゲノムシーケンスすることにより突然変異遺伝子や QTL を迅速に同定できる技術で，有用性が高い，

本稿で示した水稲に限らず, 効率良い作物ゲノム育種 を推進する上で, 対象作物の広い遺伝的変異を, すぐに 利用できる形で保有していることが前提となる，突然変 異系統作出や，大規模 RIL 育成はこうした目的に応える 取り組みである。大規模遺伝資源に対して，NGSによる

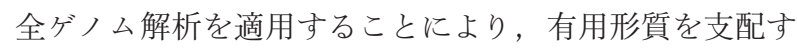
る遺伝子領域を迅速に明らかにすることができる。同定 された領域に DNA マーカーを開発して使用することに
より，育種を飛躍的に迅速化できるものと期待している.

演題 4 GBS を利用した野生イネと栽培イネの交雑に由 来する $\mathrm{F}_{2}$ 集団における QTL 解析

古田智敬 ${ }^{1}$, Stefan Reuscher ${ }^{1}$, 朱 新矢 ${ }^{2}$, Rosalyn B. Angeles-Shim $^{1}$, 上原奏子 ${ }^{1}$, 近藤宏野 ${ }^{1}$, 土井一行 ${ }^{2}$, 芦 苅基行 ${ }^{1}$ (1. 名大・生物機能開発利用研究センター, 2. 名大院・生命農学)

NGS の登場以来，それを利用した様々な遺伝解析手法 が開発されてきた. その一つに, Genotyping-by-Sequencing （GBS）がある. GBS とは Restriction site associated DNA sequencing（RAD-Seq）と呼ばれる手法と同様で, NGS により制限酵素切断部位近傍の配列を取得し, 種間や品 種間を比較した際に，そこに含まれる SNPs によって遺 伝子型判定を行ら手法である (Baird et al. 2008, Poland et al. 2012). 本方法では, 全ゲノムシーケンスにより SNPs 検出を行ら場合に比べ大幅にシーケンス対象領域を減ら すことで，1 ランで数十から数百検体を処理し，スピー ドやコストパフォーマンスを大幅に向上させることがで きるため, RFLP マーカーやマイクロサテライトマーカー をもとにした遺伝子型判定法に代わる強力な遺伝学的解 析ッールとして普及が期待される.

講演では, イネ栽培品種 Oryza sativa L. cv. Nipponbare とイネ野生種 O. longistaminata の $\mathrm{F}_{2}$ 交雑集団 1,081 個体 に対して, GBS 法による遺伝子型判定を行い, 分げつ数 について QTL 解析を行った結果を紹介した。本研究で は， $\mathrm{F}_{2}$ 個体から抽出したDNAを KpnI と Msp I で処理し, 96 サンプル分を1 ライブラリーとして調整を行い MiSeq （Illumina）によりシーケンシングを行った。データ解析 は, TASSEL-GBSソフトウェアを利用した (Glaubitz et al. 2014). シーケンスデータは, 日本晴ゲノムをリファ レンスとしてマッピングを行い, SNPs を検出した. MiSeq では 1 ランでおよそ 2500 万リードのシーケンスデータが 得られ，37,938 個の SNPs がコールされたが，多くの SNPs は何らかのエラーによるものであった. このデータ に対して，マイナー対立遺伝子頻度（MAF）などを利用 して各 SNPs のクオリティチェックを行い，信頼性が高 く遺伝子型判定に利用可能な SNPs のみを抽出した結果, 1,096 個の SNPs が得られた。 しかしながら, 得られた遺 伝子型データには GBS 特有のエラーや野生種との交雑集 団特有と思われるエラーが多量に含まれていた。最子頻 繁に見られるエラーは，へテロ接合部位のアンダーコー ルである。これは，染色体上で隣接する SNPs に扔いて 遺伝子型が，へテローホモーへテロとなるようなエラー のことである. このエラーは SNP 当たりのリード数が少 なく, 偶然片親に由来するシーケンスの及得られた場合 に, 誤ってホモ接合として判定してしまらために発生す る。一方，ホモ接合に挟まれた SNPがへテロ接合と判定 されるアンダーコールとは逆パターンのエラーも存在し た。これは, 日本晴ゲノム中では重複の無い配列だが, 
O. longistaminata ゲノム中では重複が起こっているため に, 重複配列に由来する O. longistaminata 型のリードデー タが混ざることでへテロ型として判定されているものと 考えられた。 そこで, これらのエラーを修復し，可能な らば欠損值を穴埋めする簡易なアルゴリズムを作成し データの修正を行った。 これにより，遺伝子型データを 用いて遺伝地図を作製した際，データ修正前の染色体サ イズが 1,000-3,000 cM だったものが，データ修正後に は，100-200 cM と大きく改善された. この遺伝子型デー タと分げつ数データをもとに QTL 解析を行ったところ, 染色体 1，3，4，8 に有意な QTLs が検出された。また， 1,081 個体のらちからランダムに 200 個体を抽出して QTL 解析を行うことを 100 回繰り返した結果, 200 個体 に打ける解析では，3，4，8 番染色体上の QTL は効果が 小さいために有意な QTL として検出できない可能性が高 いことが示された.

本研究で示された通り, 多検体解析を行らことは統計 的な検出力を向上させ QTL 解析を行ら上で大きなメリッ トとなる。しかしながら，1,000 個体以上からなる集団の 全ゲノム遺伝子型を RFLP マーカーやマイクロサテライ トマーカーによって判定するには膨大な時間と労力を必 要とし，実質的に非常に困難であった。しかし，GBS 法 を用いることで, 数千個体に打ける大規模解析も不可能 ではなくなった。実際，本研究では，合計 1,081 個体の $\mathrm{F}_{2}$ 個体を解析に用いたが，遺伝子型判定に要した日数は およそ 2 週間程度であった。 今後, 様々な非モデル生物 や野生種との交雑集団で GBS 法を利用するにあたって, 様々な集団特有のエラーをどう処理するかが大きな問題 となると考えられる。しかしながら，GBS 法は遺伝学・ 育種学に和ける強力な必須のツールとなることは間違い ないと思われる。

\section{演題 5 画像解析による圃場での高速フェノタイピング 郭威 ${ }^{1}$, 深津時広 ${ }^{2}$, 渡辺 翔 ${ }^{1}$, 岩田洋佳 ${ }^{1}$, 二宮正 $士^{1}$ （1．東大院・農生，2. 農研機構・中央農研）}

近年の NGSの発達はゲノム解析の革新的な高速化と 高出力化を実現し，さまざまな植物種のゲノム配列解析 を可能とした，その一方で，表現型解析は，多くの場合， 破壊的でから労力を要し, ゲノム研究や育種のボトルネッ クとなっている。こらした状況は，とりわけ野外圃場で 顕著である。これまでもっぱら定性的に行われてきた表 現型解析の客観化や定量化のための研究も行われてきた が，多くの場合は破壊的で，固場での経時的かつ高速な 解析には必ずしも適していなかった。

農業分野における表現型解析では，固場で栽培され生 育する作物を対象とし，環境と遺伝子型の交互作用を含 めた実際的なパフォーマンスを評価する必要がある。し かし，これまでに開発された手法は，撮影条件が整った 室内環境下で撮影された画像を主な解析対象としており, 光環境が時間的に変化する野外の複雑な条件下で撮影さ
れた画像には適応できない場合が多かった。いっぽう， フィールドサーバなどの機器を用いて野外環境を測定し ながら高頻度に時系列の作物画像を収集できるように なっており，こうした時系列画像を連続的に評価するこ とで，時間変化にともなら新たな形質変異の評価の可能 性に期待が高まっている.

そこで, 本研究では, 近年急速に発展しているフィー ルドモニタリングシステムや無人航空機（ドローン）を 画像解析技術と組又合わせ, 野外でも使える低コス卜・ 高速フェノタイピングのための技術開発を行い, 効率的 な育種はもとより，作物生育状況の高速で逐次的な把握 によって，生産現場に扣ける栽培管理の最適化にも貢献 することを目的として行った。材料として，世界的にも 重要な穀物の一つであるコムギ，水稲，ソルガムを対象 に野外圃場で連続的に撮影されたデジタル画像から, 非 破壊で作物の外観形質（例えば，被覆率，草姿，キャ） ピー構造，株高，開花出穂）を連続的に計測するための 手法を開発し，それを野外での低コスト・高出力フェノ タイピングシステムへ取り込むことを目指した。なお， 本研究では, 実際の現場での利用を想定して, 画像セン サーのコスト, 取り扱いの容易性, 現在目視で評価され ている形質評価の高速化について勘案し, RGB 画像に対 象を限定し研究を行った。

\section{おわりに}

従来, QTL の原因遺伝子の単離には, QTL 解析から高 精度連鎖解析を行らマップベース法が主流であった。現 在ではNGS の普及が進み, 多くの研究者が大量の塩基配 列データを手にできるようになり，また，それに見合ら 規模と品質をもつ解析材料が考案され整備されつつある. これにより, 形質変異の原因遺伝子の同定を効率的に行 えることが示された。 また，遺伝解析の精度を向上させ るためには，マッピング集団の大規模化や形質評価手法 の改善が必要であることが明らかとなった。一方, NGS の大規模データを扱らための統計手法は多くの作物でヒ トと比較して未成熟であり, 従来型のバイオインフォマ ティクスとは別の分野の統計解析手法（ネットワーク解 析や高度なモデリングなど）により，さらに多くの情報 を引き出せる余地が残っている。ここでは, 単に遺伝子 の単離を目指すだけでなく，微小な効果あるいは非対立 遺伝子間相互作用などを持つゲノム領域を同定し，「失わ れた遺伝率」問題を解決するような方向での進歩が期待 される。

育種学系の実験室の風景は 20 年前から大きく変化し たが，NGSにより，遺伝子型決定の部分は完成の域に達 したと考学られる. 一方, 試験圃場の風景は多くの研究 室・試験場で長らく大きな変化はないのではないだろら か? 近年, 画像解析や高度なセンサーのコストは劇的に 低下しているため, 形質評価の効率化が新たな研究分野 
として広がり，NGSデータに見合ら表現型データが収集 できるようになるであろら。これにより，大規模集団を 利用したより統計的検出力が高い遺伝解析や，遺伝子 型一環境一圃場管理間の相互作用 (GxExM) の解析など が加速すると期待できる。

多くの分野でさらなる研究が必要であるが，実際の國 場での作物のパフォーマンスを最大化するための，真に 有意義な NGS の利用法の発展が望まれる。

\section{謝 辞}

ワークショップにご参加下さった多数の方々にお礼申 し上げます。また，ワークショップの開催にあたりご協 力下さった大会運営委員会・シンポジウム委員会・会場 スタッフの皆様に拈礼申し上げます。本ワークショップ はNBRP「コムギ」，NBRP「イネ」，CREST「二酸化炭 素資源化を目指した植物の物質生産力強化と生産物活用 のための基盤技術の創出」，戦略的イノベーション創造プ ログラム（SIP）「戦略的オミクス育種技術体系の構築」 の協賛で行われた。

\section{引用文献}

Abe, A., S. Kosugi, K. Yoshida, S. Natsume, H. Takagi, H. Kanzaki, H. Matsumura, K. Yoshida, C. Mitsuoka, M. Tamiru et al. (2012) Genome sequencing reveals agronomically important loci in rice using MutMap. Nat. Biotechnol. 30: 174-178.

Baird, N.A., P.D. Etter, T.S. Atwood, M.C. Currey, A.L. Shiver, Z.A. Lewis, E.U. Selker, W.A. Cresko and E.A. Johnson (2008) Rapid

\section{当日 演題}

はじめに 土井一行 (名古屋大学大学院生命農学研究科)
SNP discovery and genetic mapping using sequenced RAD Markers. PLoS ONE 10: e3376.

Barabasi, A.L. and R. Albert (1999) Emergence of scaling in random networks. Science 286: 509-512.

Glaubitz, J.C., T.M. Casstevens, F. Lu, J. Harriman, R.J. Elshire, Q. Sun and E.S. Buckler (2014) TASSEL-GBS: A high capacity genotyping by sequencing analysis pipeline. PLoS ONE 9: e90346.

IWGSC (2014) A chromosome-based draft sequence of the hexaploid bread wheat (Triticum aestivum) genome. Science 345: 1251788.

Poland, J.A., P.J. Brown, M.E. Sorrells and J.L. Jannink (2012) Development of high-density genetic maps for barley and wheat using a novel two-enzyme genotyping-by-sequencing approach. PLoS ONE 7: e32253.

Price, A., N. Zaitlen, D. Reich and N. Patterson (2010) New approaches to population stratification in genome-wide association studies. Nat. Rev. Genet. 11: 459-463.

Rakshit, S., H. Kanzaki, H. Matsumura, A. Rakshit, T. Fujibe, Y. Okuyama, K. Yoshida, O.M. Tamiru, M. Shenton, H. Utsushi et al. (2010) Use of TILLING for reverse and forward genetics or rice. In "The Handbook of Plant Mutation Screening" Meksem, K. and G. Kahl (eds.), Wiley-VCH, 185-197.

Speed, D. and D.J. Balding (2015) Relatedness in the post-genomic era: is it still useful? Nat. Rev. Genet. 16: 33-44.

Takagi, H., A. Abe, K. Yoshida, S. Kosugi, S. Natsume, C. Mitsuoka, A. Uemura, H. Utsushi, M. Tamiru, S. Takuno et al. (2013) QTL-seq: rapid mapping of quantitative trait loci in rice by whole genome resequencing of DNA from two bulked populations. Plant J. 74: 174-183.

Yu, J., J.B. Holland, M.D. McMullen and E.S. Buckler (2008) Genetic design and statistical power of nested association mapping in maize. Genetics 178: 539-551.

\section{講演}

1. 育種に和ける遺伝統計学

田宮 元（東北大・東北メディカル・メガバンク機構）

2. コムギ倍数性シリーズ（AA, $\mathrm{AABB}, \mathrm{AABBDD} ）$ のアコレクションの作成と利用 那須田周平 (京大院・農学)

3. イネ大規模突然変異集団と交配集団を用いた遺伝子領域同定 寺内良平・阿部 陽・高木宏樹・神崎洋之・夏目 俊 - 八重樫弘樹・宇津志博恵・植村亜衣子・神崎英子・ タミルムルネー（公益財団法人岩手生物工学研究センター）

4. GBS を利用した野生イネと栽培イネの交雑に由来する $\mathrm{F}_{2}$ 集団における QTL 解析 古田智敬 ${ }^{1} \cdot$ Stefan Reuscher $^{1}$ ・朱 新吴 ${ }^{2} \cdot$ Rosalyn B. Angeles-Shim $^{1} \cdot$ 上原奏子 ${ }^{1} \cdot$ 近藤宏野 ${ }^{1} \cdot$ 土井一行 ${ }^{2} \cdot$ 芦䓭基行 ${ }^{1}$ （1. 名大・生物機能開発利用研究センター， 2. 名大院・生命農学）

5. 画像解析による戋場での高速フェノタイピング

郭 威 ${ }^{1}$ 深津時広 ${ }^{2} \cdot$ 渡辺 翔 $^{1}$ ・岩田洋佳 ${ }^{1} \cdot$ 二宮正士 ${ }^{1}$ (1. 東大院・農生, 2 . 農研機構・ 中央農研 $)$ 